\title{
Rancang Bangun Seleksi Kendaraan Sederhana Menggunakan Sensor HC-SR04
}

\author{
Nissa Sukmawati ${ }^{*}$, Asti Sawitri ${ }^{2}$, dan M. Rizki G.N ${ }^{3}$ \\ ${ }^{1}$ Prodi Fisika UIN Sulthan Thaha Saifuddin Jambi; \\ ${ }^{2}$ Prodi Fisika UIN Sunan Gunung Djati Bandung; \\ ${ }^{3}$ Politeknik Manufaktur Bandung; \\ email: ${ }^{* 1}$ nissa.sukmawati@ uinjambi.ac.id, ${ }^{2}$ sawitriasti@ gmail.com, ${ }^{3}$ rizkigorby@ gmail.com
}

\begin{abstract}
Abstrak
Penelitian ini bertujuan untuk merancang sistem seleksi kendaraan sederhana berdasarkan ketinggian dan panjang kendaraan menggunakan sensor HC-SRO4 dengan mikrokontroler arduino UNO. Sistem ini terdiri dari sensor ultrasonik HC-SR04 yang memancarkan gelombang ultrasonic kemudian diterima oleh receiver lalu diolah menjadi sebuah data berupa ketinggian dan panjang untuk menentukan golongan kendaraan. Metode penelitian ini dilakukan dengan mengukur ketinggian dan panjang kendaraan yang melewati sensor sehingga golongan kendaraan dapat ditentukan. Penelitian terbatas pada kendaraan box golongan III, IV, dan V. Hasil dari rancang bangun seleksi kendaraan dengan menggunakan sensor HC-SR04 sangat layak digunakan untuk seleksi kendaraan.
\end{abstract}

Kata kunci-HC-SR04, seleksi kendaraan, ultrasonik, Arduino Uno

\section{PENDAHULUAN}

Jalan tol adalah jalan yang dibuat untuk memperlancar arus lintas dan meningkatkan distribusi barang dan jasa. Pada dasarnya, jalan tol telah mampu berfungsi sebagaimana mestinya. Permasalahan utama yang sering dialami oleh jalan tol adalah adanya antrean kendaraan saat masuk ataupun keluar dari jalan tol (Listyono dkk, 2015). Untuk mengurangi antrean, salah satu solusi yang ditawarkan adalah penggunaan Gardu Tol Otomatis (GTO). Pada GTO, sistem pembayaran tol tidak lagi menggunakan uang tunai, melainkan menggunakan kartu yang disentuhkan pada mesin GTO (Wasistha, 2017). Dengan penggunaan GTO tersebut, pengguna jalan tol dapat menghemat waktu pembayaran dan tidak perlu berinteraksi dengan petugas secara langsung sehingga dapat menghemat waktu hingga 4-7 detik. Penggunaan GTO tentu dilengkapi dengan teknologi canggih yang mampu membedakan golongan kendaraan. Pembedaan golongan kendaraan berkaitan dengan jumlah nominal yang harus dibayarkan ketika melewati jalan tol. Jenis golongan kendaraan yang berbeda akan dikenakan besaran tarif yang berbeda.

Berdasarkan Keputusan Menteri Pekerjaan Umum No. 370/KPTS/M/2007, terdapat 6 golongan kendaraan yang disajikan pada Tabel 1.

Tabel 1 Golongan kendaraan berdasarkan Keputusan Menteri Pekerjaan Umum No. 370/KPTS/M/2007

\begin{tabular}{|c|l|l|}
\hline No. & \multicolumn{1}{|c|}{ Golongan } & \multicolumn{1}{c|}{ Jenis Kendaraan } \\
\hline 1. & Golongan I & Sedan, Jip, Pick Up/Truk Kecil, dan Bus \\
\hline 2. & Golongan II & Truk dengan 2 (dua) gandar \\
\hline 3. & Golongan III & Truk dengan 3 (tiga) gandar \\
\hline 4. & Golongan IV & Truk dengan 4 (empat) gandar \\
\hline 5. & Golongan V & Truk dengan 5 (lima) gandar \\
\hline 6. & Golongan VI & Kendaraan bermotor roda 2 (dua) \\
\hline
\end{tabular}


Berbeda dengan gerbang tol biasa yang penentuan golongan kendaraannya ditentukan oleh operator yang ditempatkan di pos gardu tol, pada GTO digunakan sensor untuk mendeteksi golongan kendaraan. Salah satu sensor yang digunakan adalah sensor Optical Beam Sensor yang menggunakan sensor infrared untuk mendeteksi kendaraan. Sensor ini mulai ditinggalkan dan beralih ke sensor Automatic Vehicle Classification $(A V C)$. AVC memiliki sensor yang lebih banyak dibandingkan Optical Beam Sensor sehingga menunjukkan hasil yang lebih akurat (Widodo Groho, 2019).

Terdapat beberapa teknologi yang dapat digunakan untuk seleksi kendaraan. Antara lain loop detector, infra merah, ultrasonik, radar, gelombang mikro, dan deteksi dengan video (Harlow \& Peng, 2001). dari beberapa pilihan tersebut, peneliti mencoba untuk menciptakan sensor sederhana menggunakan sensor ultrasonik yang mampu mendeteksi beberapa jenis golongan kendaraan. Sensor ini dapat menyeleksi kendaraan berdasarkan jenis dan golongan mobil dari ketinggian dan panjang kendaraan. Hal tersebut dapat memudahkan dalam pembayaran e-toll sesuai dengan kendaraan yang digunakan. Pada penelitian kali ini jenis mobil yang akan dibedakan dibatasi hanya pada mobil box yang tergolong dalam golongan III, IV dan V. Golongan III, IV, dan V adalah kendaraan dengan ban bergandar yang memiliki bentuk dimensi tidak terlalu berbeda satu sama lain, sehingga sulit untuk dibedakan apabila ditinjau berdasarkan dimensinya. Oleh karena itu seleksi kendaran untuk golongan ini yang menjadi fokus penelitian.

Sensor ultrasonik merupakan sensor yang menggunakan gelombang ultrasonik dengan frekuensi $20 \mathrm{kHz}$ sampai $2 \mathrm{MHz}$. Sensor ultrasonik terdiri dari rangkaian pemancar ultrasonik yang disebut transmitter dan rangkaian penerima ultrasonik yang disebut receiver. Sinyal ultrasonik yang dibangkitkan akan dipancarkan dari transmitter ultrasonik. Sinyal yang dipancarkan tersebut kemudian akan merambat sebagai sinyal/ gelombang bunyi. Ketika gelombang ultrasonik yang dipancarkan oleh transmitter mengenai penghalang, maka sinyal ini akan dipantulkan dan diterima oleh receiver. Jarak sensor dan objek adalah setengah dari jarak tempuh sinyal dan dapat diperoleh dengan mengetahui lama waktu penjalaran sinyal. Sensor ultrasonic dapat digunakan untuk mengukur jarak maupun digunakan pada pemetaan (Niku, 2011)

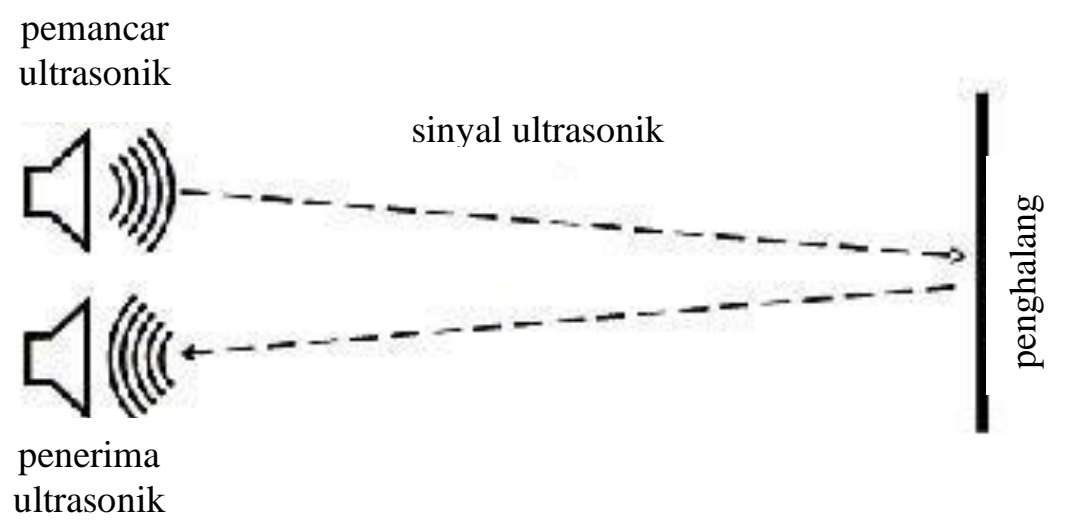

Gambar 1 Prinsip kerja sensor ultrasonik

Sensor ultrasonik yang tepat digunakan untuk alat seleksi kendaraan e-toll adalah sensor yang memiliki ketepatan pengukuran yang baik pada jangkauan jarak yang jauh maupun dekat. Seperti sensor HC-SR04 yang memiliki jarak pengukuran 2- $400 \mathrm{~cm}$. Jangkauan jarak ini cukup untuk digunakan pada pengukuran penelitian ini (indo-ware.com).

Pengolahan data pada penelitian ini menggunakan Mikrokontroler Arduino Uno. Arduino Uno memiliki kaki digital input dan output berjumlah 14. Terdapat 6 kaki yang digunakan sebagai sinyal Pulse Width Modulator (PWM) yang menghasilkan analog output yang diinginkan. Selain itu, Arduino Uno juga memiliki 
https://jurnal.unsulbar.ac.id/index.php/saintifik

6 kaki analog input, koneksi USB, konektor listrik, kaki IheaderI dari ICSP dan tombol reset untuk mengatur ulang program (Magdalena, Greisye and Halim, Fransiscus Ati and Aribowo, 2013).

\section{METODE PENELITIAN}

Penelitian yang dilakukan terdiri pada beberapa tahap yaitu, kalibrasi sensor, membuat prototype alat seleksi kendaraan, dan uji coba alat seleksi kendaraan. Pada penelitian ini digunakan sensor HC-SR04 sebagai sensor pendeteksi jarak serta perangkat arduino uno untuk pengolahan data.

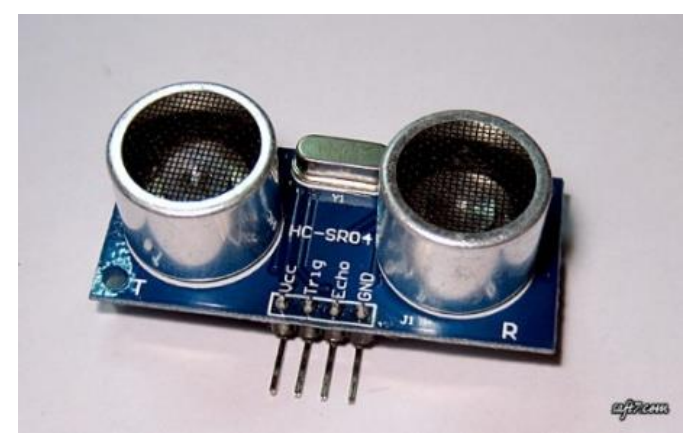

Gambar 2 Sensor HC-SR04

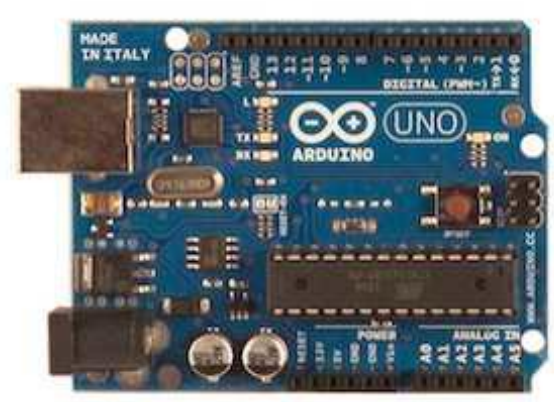

Gambar 3 Arduino Uno

Kalibrasi sensor dilakukan dengan menempatkan sensor HS-CR04 pada jarak tertentu dengan objek dan membandingkan hasil yang dibaca oleh sensor dengan jarak yang sebenarnya. Pengambilan data kalibrasi dilakukan dengan selisih $10 \mathrm{~cm}$ setiap data pada jarak $10-400 \mathrm{~cm}$. Selisih data $10 \mathrm{~cm}$ setiap pengujian bertujuan untuk memastikan sensor HS-CR04 memiliki ketepatan yang tinggi sehingga baik digunakan.

Tahap kedua penelitian yaitu pembuatan prototype alat seleksi kendaraan beserta media ukurnya. Prototype dibuat dengan perbandingan 1:10 dengan data dimensi kendaraan sebenarnya pada setiap golongan.

Tabel 2 Data dimensi kendaraan rata-rata

\begin{tabular}{|c|c|c|c|}
\hline Golongan kendaraan & Panjang $(\mathrm{cm})$ & Lebar $(\mathrm{cm})$ & Tinggi $(\mathrm{cm})$ \\
\hline III & 430 & 250 & 200 \\
\hline IV & 500 & 250 & 250 \\
\hline V & 600 & 250 & 250 \\
\hline
\end{tabular}




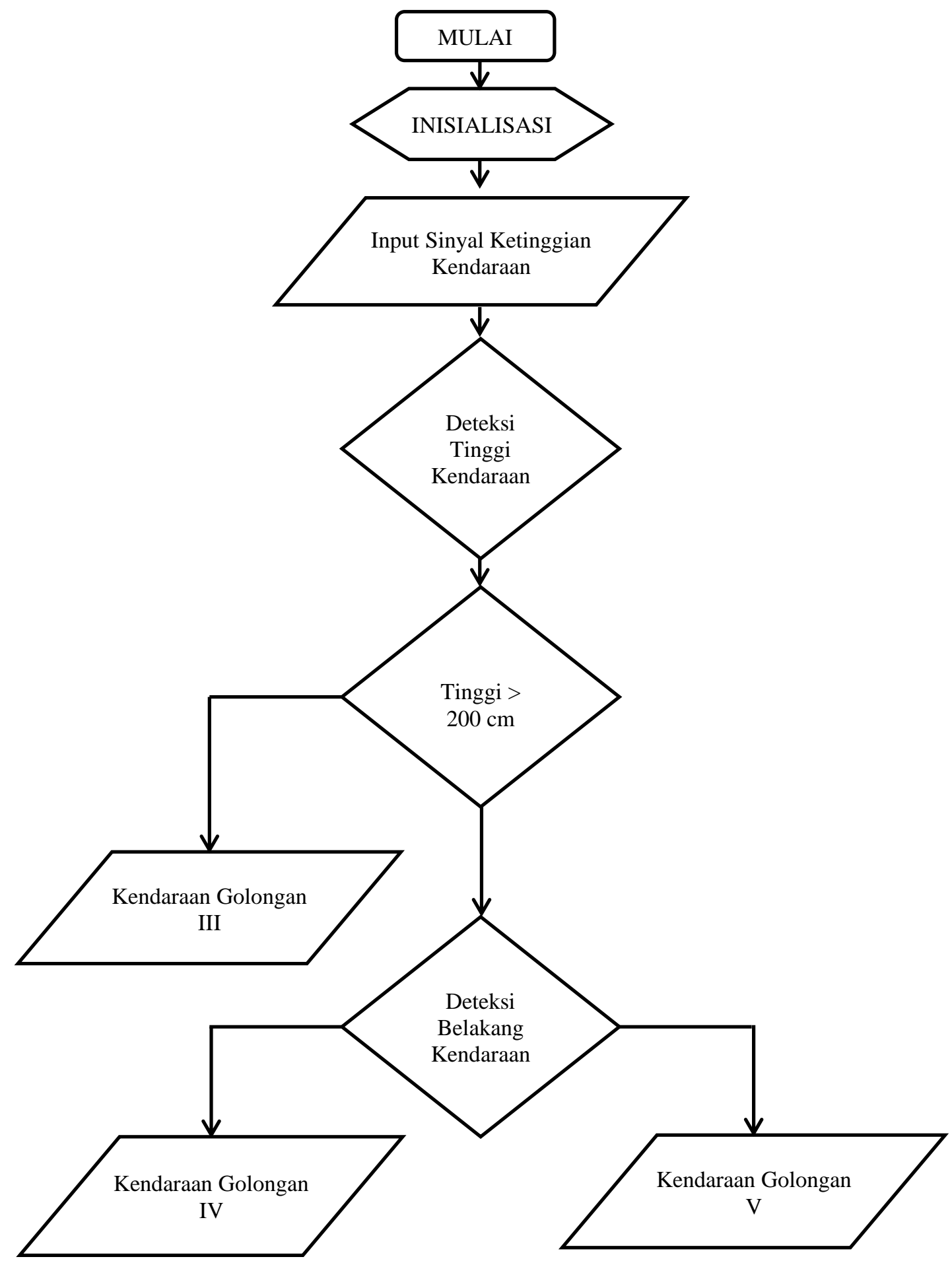

Gambar 4. Bagan sistem kerja sensor seleksi kendaraan

Tahap selanjutnya pada penelitian yaitu tahap uji coba alat seleksi kendaraan. Tahap ini dilakukan dengan memasang dua buah sensor HC-SR04 di atas tempat kendaraan yang berhenti untuk membayar tol. Sensor dipasang di bagian atas dan akan mengukur jarak pantulan yang akan mendeteksi keberadaan kendaraan. Kendaraan yang dimaksud dalam penelitian ini adalah mobil box dengan beberapa ukuran. Karena 
setiap golongan kendaraan mempunyai tinggi dan panjang kendaraan yang berbeda maka hal tersebut dapat digunakan sebagai dasar pembuatan alat seleksi.

Sensor pertama diletakkan di atas bagian depan box kendaraan. Jika sensor mendeteksi kendaraan dengan ketinggian $200 \mathrm{~cm}$, maka sensor akan menyimpulkan bahwa kendaraan masuk dalam golongan III. Selanjutnya, jika sensor mendeteksi kendaraan dengan ketinggian lebih dari $200 \mathrm{~cm}$, maka sistem seleksi dilanjutkan oleh sensor kedua. Sensor kedua diletakkan di bagian atas belakang kendaraan. Karena adanya perbedaan panjang kendaraan golongan IV dan golongan $\mathrm{V}$, maka sensor diatur berada di antara selisih panjang tersebut. Jika sensor mendeteksi adanya kendaran yang memiliki ketinggian yang sama dengan sensor pertama, maka disimpulkan kendaraan termasuk dalam golongan $\mathrm{V}$. namun jika sensor tidak mendeteksi adanya kendaraan atau terdapat kendaraan yang lebih rendah, maka disimpulkan bahwa kendaraan termasuk golongan IV. Algoritma sistem seleksi kendaraan disajikan lebih lengkap pada Gambar 4.

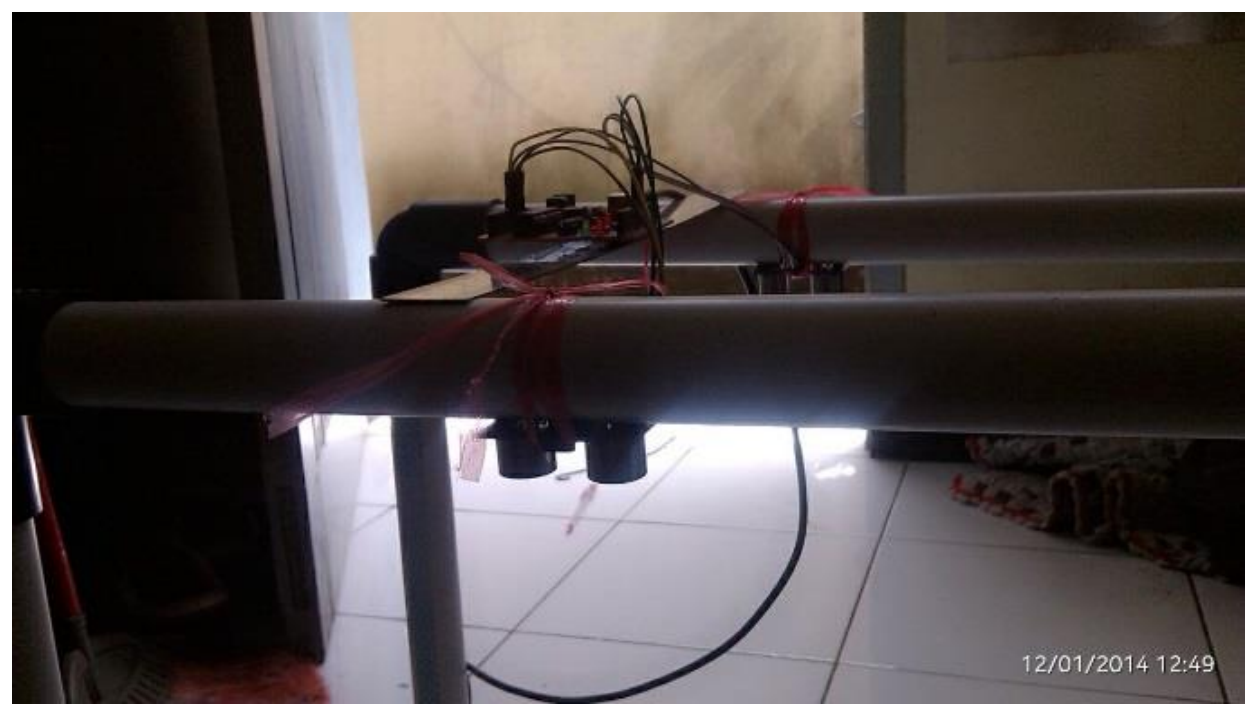

Gambar 5 Rangkaian alat seleksi kendaraan
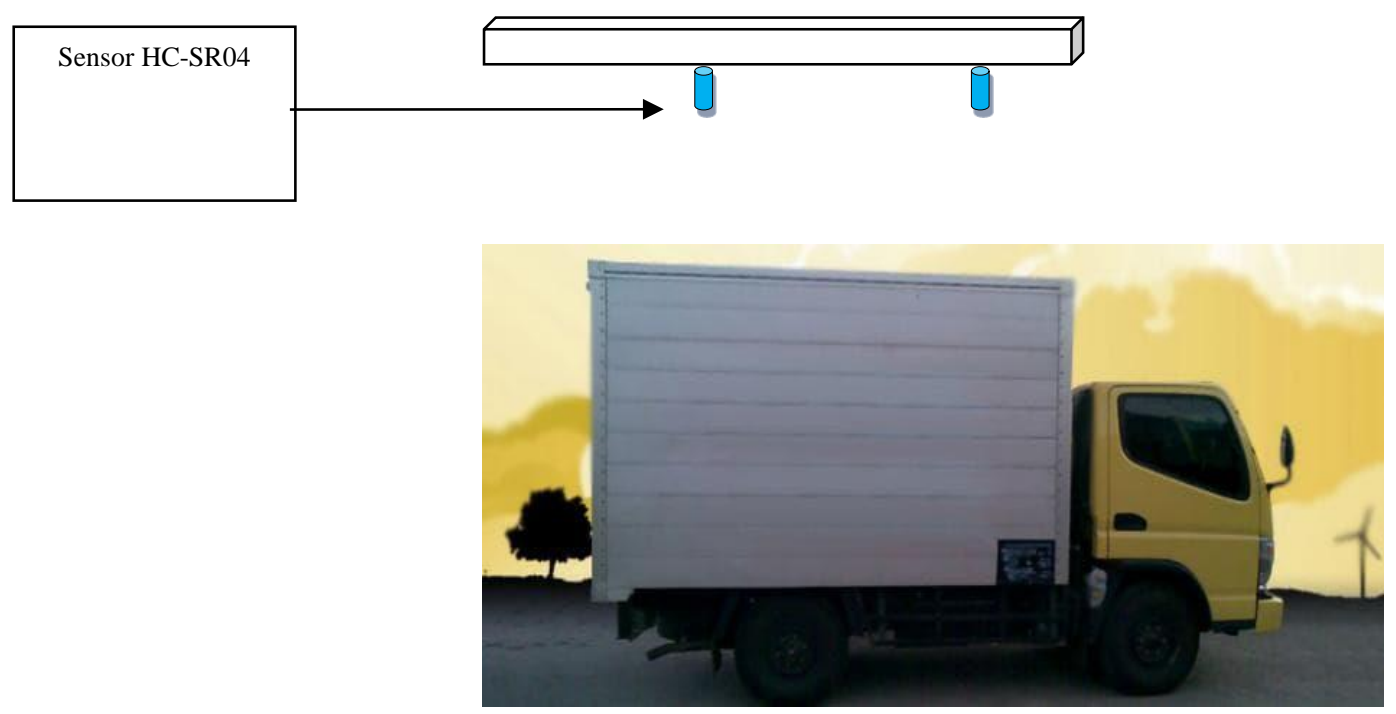

Gambar 6 Rancang bangun penelitian 
https://jurnal.unsulbar.ac.id/index.php/saintifik

\section{HASIL DAN PEMBAHASAN}

Hasil kalibrasi sensor HC-SR04 ditunjukkan pada Tabel 3 dan disajikan dalam Grafik 1. Kalibrasi dilakukan dengan pengukuran pada jarak 10 hingga $400 \mathrm{~cm}$ dengan selang jarak $10 \mathrm{~cm}$. Tabel 3 menunjukkan bahwa pada setiap jarak pengukuran, perbedaan antara jarak sebenarnya dan jarak hasil pengukuran antara 0 $-4 \mathrm{~cm}$. Semakin jauh jarak pengukuran, maka semakin kecil nilai error yang dihasilkan. Hal ini menunjukkan bahwa sensor HC-SR04 relatif lebih baik digunakan untuk pengukuran jarak dengan jangkauan yang lebih jauh. Jangkauan maksimal pengukuran jarak HC-SR04 adalah $450 \mathrm{~cm}$.

Tabel 3. Data kalibrasi sensor HC-SR04

\begin{tabular}{|c|c|c|c|c|c|c|c|}
\hline No. & $\begin{array}{c}\text { Jarak } \\
\text { Sebenarnya } \\
(\mathrm{cm})\end{array}$ & $\begin{array}{c}\text { Jarak } \\
\text { Pengukuran } \\
(\mathrm{cm})\end{array}$ & $\begin{array}{c}\text { Selisih Jarak } \\
\text { Sebenarnya } \\
\text { dan } \\
\text { Pengukuran } \\
(\mathrm{cm})\end{array}$ & No. & $\begin{array}{c}\text { Jarak } \\
\text { Sebenarnya } \\
(\mathrm{cm})\end{array}$ & $\begin{array}{c}\text { Jarak } \\
\text { Pengukuran } \\
(\mathrm{cm})\end{array}$ & $\begin{array}{c}\text { Selisih Jarak } \\
\text { Sebenarnya } \\
\text { Pengukuran } \\
(\mathrm{cm})\end{array}$ \\
\hline 1 & 10 & 10,71762376 & 0,71762376 & 21 & 210 & 207,0948515 & 2,9051485 \\
\hline 2 & 20 & 20,68079208 & 0,68079208 & 22 & 220 & 217,2875248 & 2,7124752 \\
\hline 3 & 30 & 30,44405941 & 0,44405941 & 23 & 230 & 226,8894059 & 3,1105941 \\
\hline 4 & 40 & 40,18792079 & 0,18792079 & 24 & 240 & 237,000297 & 2,999703 \\
\hline 5 & 50 & 49,62871287 & 0,37128713 & 25 & 250 & 246,9422772 & 3,0577228 \\
\hline 6 & 60 & 59,38138614 & 0,61861386 & 26 & 260 & 257,159605 & 2,840395 \\
\hline 7 & 70 & 69,09584158 & 0,90415842 & 27 & 270 & 267,1573267 & 2,8426733 \\
\hline 8 & 80 & 79,3450495 & 0,6549505 & 28 & 280 & 277,2729703 & 2,7270297 \\
\hline 9 & 90 & 89,58891089 & 0,41108911 & 29 & 290 & 287,0828713 & 2,9171287 \\
\hline 10 & 100 & 98,50326733 & 1,49673267 & 30 & 300 & 296,9609901 & 3,0390099 \\
\hline 11 & 110 & 108,4631683 & 1,5368317 & 31 & 310 & 307,0893069 & 2,9106931 \\
\hline 12 & 120 & 118,0292079 & 1,9707921 & 32 & 320 & 317,1991089 & 2,8008911 \\
\hline 13 & 130 & 128,1060396 & 1,8939604 & 33 & 330 & 327,0370297 & 2,9629703 \\
\hline 14 & 140 & 138,0644554 & 1,9355446 & 34 & 340 & 336,9261386 & 3,0738614 \\
\hline 15 & 150 & 147,5728713 & 2,4271287 & 35 & 350 & 346,7 & 3,3 \\
\hline 16 & 160 & 157,7579208 & 2,2420792 & 36 & 360 & 356,7488119 & 3,2511881 \\
\hline 17 & 170 & 167,3549505 & 2,6450495 & 37 & 370 & 366,8 & 3,2 \\
\hline 18 & 180 & 177,5111881 & 2,4888119 & 38 & 380 & 376,5863366 & 3,4136634 \\
\hline 19 & 190 & 187,0746535 & 2,9253465 & 39 & 390 & 387,1171287 & 2,8828713 \\
\hline 20 & 200 & 197,4791089 & 2,5208911 & 40 & 400 & 396,3375248 & 3,6624752 \\
\hline
\end{tabular}




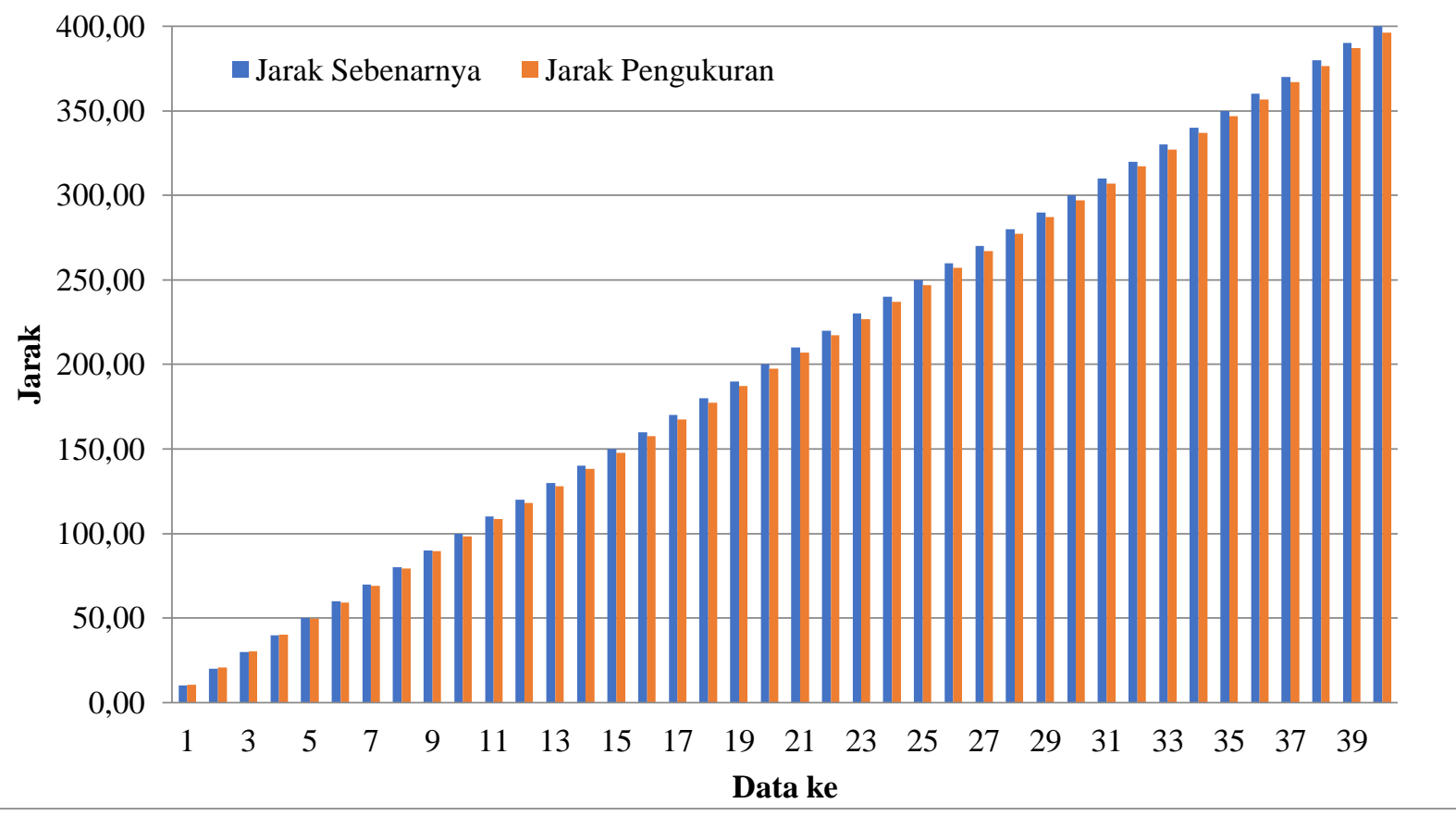

Grafik 1 Data kalibrasi sensor HC-SR04

Kalibrasi sensor dilakukan dengan mengkondisikan sekitar area objek ukur tanpa penghalang. Hal ini dilakukan karena kalibrasi hanya bertujuan untuk mengetahui tingkat ketepatan pembacaan sensor terhadap jarak yang sebenarnya. Pembacaan sensor terhadap jarak sebenarnya memiliki ketepatan sebesar 98,66\%. Hal ini menunjukkan kelayakan penggunaan sensor untuk aplikasi alat seleksi kendaraan pada $e$-toll.

Selanjutnya dilakukan seleksi kendaraan pada prototype yang telah dibuat. Pengujian dilakukan dengan melewatkan kendaraan prototype yang telah dibuat pada penghalang yang telah diletakan dua buah sensor untuk mengukur tinggi dan panjang kendaraan tersebut kemudian data tersebut diolah menggunakan mitrokontroler arduino uno sehingga data tersebut berubah menjadi golongan kendaraan yang sesuai dengan kendaraan yang diukur. Pengujian dilakukan berulang dengan hasil yang konstan dan disajikan pada Tabel 4.

Tabel 4 Hasil uji coba prototype

\begin{tabular}{|c|c|c|c|c|}
\hline $\begin{array}{c}\text { Golongan kendaraan } \\
\text { seharusnya }\end{array}$ & Panjang $(\mathrm{cm})$ & Lebar $(\mathrm{cm})$ & Tinggi $(\mathrm{cm})$ & $\begin{array}{c}\text { Golongan kendaraan } \\
\text { hasil ujicoba }\end{array}$ \\
\hline III & 43 & 25 & 20 & III \\
\hline IV & 50 & 25 & 25 & IV \\
\hline V & 60 & 25 & 25 & V \\
\hline
\end{tabular}

Berdasarkan Tabel 4 terlihat ketetapan antara golongan kendaraan sebenarnya dengan golongan kendaraan menggunakan sensor HC-SR04. 
https://jurnal.unsulbar.ac.id/index.php/saintifik

\section{KESIMPULAN}

Hasil dari rancang bangun seleksi kendaraan dengan menggunakan sensor HC-SR04 sangat layak digunakan untuk seleksi kendaraan karena sensor tersebut dapat mengukur jarak hingga $400 \mathrm{~cm}$ dengan ketepatan sebesar 98,4\%. Berdasarkan hasil ujicoba prototype didapat bahwa golongan kendaraan prototype dengan pembacaan data pada display menunjukkan golongan kendaraan yang tepat. Oleh karena itu sensor ini dapat digunakan untuk menseleksi golongan kendaraan berdasarkan tinggi dan panjang kendaraan

\section{DAFTAR PUSTAKA}

Groho, W., 2019, Begini Cara Gerbang Tol Mendeteksi Jenis Dan Golongan Kendaraan. https://www.widodogroho.com/2019/08/begini-cara-gerbang-tol-mendeteksi.html, diakses tanggal 14 Januari 2020.

Harlow, C., \& Peng, S. (2001). Automatic vehicle classification system with range sensors. Transportation Research Part C: Emerging Technologies, 9(4), 231-247. https://doi.org/10.1016/S0968-090X(00)00034$\underline{6}$

Indoware, 2013, Ultrasonic Ranging Module HC - SR04, Datasheet, http://dropbox.indoware.com/files/Ultrasonic\%20HC-SR04.pdf, diakses tanggal 14 Januari 2020.

Listyono, A. F., Darjat., Wahyul A.S., (2015). Perancangan Prototipe Identifikasi Kendaraan Jalan Tol Berbasis Rfid Dan Notifikasi Pembayaran Via SMS, TRANSIENT, No. 4, Vol. 4, Hal 902-908.

Magdalena, Greisye and Halim, Fransiscus Ati and Aribowo, A. (2013). Perancangan Sistem Akses Pintu Garasi Otomatis Menggunakan Platform Android. Prosiding Csgteis, 4(4), 301-306.

Niku, S.B., 2011, An introduction to Robotics: Analysis, Control, Applications, $2^{\text {nd }}$ edition, John Wiley and Sons, USA.

Wasistha, Magistra Zuhair., 2017, Gerbang Tol Pandaan-Malang, Tugas Akhir, Departemen Teknik Sipil, Fakultas Teknik Sipil dan Perencanaan, Institut Teknologi Sepuluh November, Surabaya. 